Rev. Andrzej Proniewski

University of Biatystok

DOI: 10.15290/rtk.2019.18.03

iD 0000-0003-0382-3646

\title{
Joseph Ratzinger's (Benedict XVI) Conceptualization of Eternity
}

Eschatology reflections of Ratzinger based on the doctrine of Catholic Church which means needy to explain the truth about Heaven, Purgatory and Hell. This article clarifies the understanding of these three categories that reflect the truth about the perspective after death understood not in a reistic way but in personal relationships or their lack.

Key words: eschatology, eternity, Heaven, Purgatory, Hell.

Eternity is possible because of the Resurrection of Jesus Christ, the God-Man. The Resurrection of the Son of God demonstrates the prospect of eternal life. As Christ ushered the Kingdom of God into the world during His life on the earth, He also showed man that Heaven is possible. He explained to those who both accepted and rejected this truth how eternal life works. This teaching became absolute after His Resurrection from the dead.

What kind of options does the Son of God's Resurrection present to man? What constitutes communion with God throughout all eternity? Does the experience of union with God after death occur immediately after a person dies? And, besides union with God, are there any another prospects for eternal life? In order to address these questions, this article will analyze the writings of Benedict XVI and be organized according to the following three categories: Heaven, Purgatory, and Hell. 
Dogmatic Theology

\section{Heaven}

The concepts of Heaven, Hell, and Purgatory are some of the most important elements of the Christian faith. These concepts indicate that the end of life on earth is not, in fact, the conclusion of everything. The different conditions of existence in life after death lead to the conclusion that the concept of life after life was and continues to be important to all of humanity. Consequently, according to Pope Benedict XVI's perception of life after death, man must be held accountable before his Creator after he dies and, therefore, must undergo some kind of judgment. ${ }^{1}$

"Heaven" is an expression that is used symbolically to express that which is above-in the heavens. Christian tradition sees within this expression the fulfillment of human existence, which, through faith, is oriented toward a love without end. ${ }^{2}$ For the baptized, Heaven is not just resurrection [from the dead]. As Benedict XVI writes, the one who believes can experience a certain level of Heaven here in his life on earth. In this way, Heaven should not be presented as a figment of the human imagination, but as a hidden reality that sustains the life of every being from the beginning of its existence. From its very beginning, the world has and continues to try to separate man from reality of Heaven in different ways. Jesus Christ confirms the fact that Heaven is a place that is connected with history. Heaven exists because God became man in the person of Jesus Christ and-in so doing-bestowed on man a place within God, who is being itself. Man's experience of Heaven depends on whether and to what degree he is [united] with Christ. It is for this reason that Heaven, according to Pope Benedict XVI, must be presented strictly as a person. Ancient philosophy tried to give meaning to life after death by asserting that man must accept that which is eternal as much as possible. Values such as truth, justice, and the good were considered eternal and immutable. The more that a person embodied these virtues, the more likely he was to be remembered throughout the ages and, thus, achieve eternal life. ${ }^{3}$

Heaven became a certainty through the historical events of Christ's death and resurrection. The Son of God gives Himself unceasingly to the Father, and in doing so, as a His paschal sacrifice is perpetually present in Him. Union with Jesus, which is understood as Heaven,

P. Seewald, J. Ratzinger, Bóg i świat [God and the World], Cracow 2005, pg. 119.

2 J. Ratzinger, Śmierć $i$ życie wieczne [Eschatology: Death and Eternal Life], Warsaw 1986, pg. 253.

3 J. Ratzinger, Opera Omnia, Vol. X, Lublin 2014, pg. 628. 
means worshipping God, which fulfills the purpose of all earthly worship. ${ }^{4}$ Those in Heaven worship God in the most perfect way. This occurs in the direct relationship between God and man, which theology colloquially refers to "beholding God." In Heaven, the entire person is completely permeated by the fullness of God, Who has become "all in all" for man. Based on the assumption that Heaven consists in being with Christ, Benedict XVI points out that a "co-existence" must also exist among those who together make up the Body of Christ. He, therefore, points out the ecclesiological dimension of the concept of "Heaven." In this case, those in Heaven cannot experience even the slightest isolation because Heaven is made up of the communion of saints, which is the fulfillment of all interpersonal references. The article of faith regarding the Communion of saints and veneration of the saints is based on this concept. Man's complete openness, about which Pope Benedict writes, leads to such a strong love within the soul that it makes the soul certain that it has attained God in another person, and the other in God. The connectedness that takes place through this union does not and cannot pose any threat or loss of self. It does, however, become purified, thanks to which it can develop to the full potential of its ability. Only in this sense can one understand Heaven as something individual. Every soul sees God and feels His love in its own unique way. ${ }^{5}$ Tradition and the New Testament rightly call heaven a "prize." Heaven is the answer to man's life, which is strewn with his work and sufferings. One cannot forget, however, that Heaven is a pure gift bestowed on man by God's love. Tradition, used to speak of Heaven as the special "crown" of martyrs, virgins, and teachers of the faith. Today, however, when speaking about Heaven the Church speaks about God, Who bestows on each soul a unique fullness. In this way, no one path to God is better or more privileged than another; rather, every path should be treated as something that must be fulfilled to the greatest degree according to its uniqueness. One can achieve Heaven only through the act of giving [oneself]. When one uniting onself to Christ, the act of giving also becomes one of "receiving," and true riches are found only in sharing what one has received with others. The dimension of Christ's cosmological presence through His "exaltation" makes Him-the Resurrected-present in the world in a completely new way. The traditions and symbols associated with this concept often describe Christ's as being "seated at the right hand of the Father" after His Resurrection. This means that the

\footnotetext{
$4 \quad$ J. Ratzinger, Śmierć..., pg. 254.

$5 \quad$ Ibid, pg. 255.
} 
Dogmatic Theology

exalted Christ participates in God's reign over the history of the world. The Son of God is not outside of the world; rather, He is above it and approaches it. Participation in Christ in this manner is precisely the "Heaven" about which we speak. This is so because Heaven should not be understood in terms of human space or in terms of existing solely outside of human space. Benedict XVI also emphasizes that Heaven is a "state" that is connected in some sense with the cosmos. Heaven is a power that manifests itself within the Body of Christ, meaning within the Communion of the saints. Using the expression "on high" does not mean a place or location in spacial terms; rather, expresses the elevation and liberation of man from bondage to what is earthly, which restrains him. Heaven is turning to the powerful force of love. Therefore, Heaven should not be separated from the earth or treated as a separate, higher level [of existence]. Many different images of Heaven are contained within the Holy Scriptures. Most often, however, Scripture repeats the truth that words cannot describe this realm. The New Testament speaks about a new heaven and a new earth in order to emphasize that all of creation is destined for the glory of God, meaning unceasing and eternal happiness. ${ }^{6}$

Scholasticism upholds that Heaven is an eschatological reality, which means that it is also something both final and completely new. God's irrevocable and undivided love bestowed on every person is part of the finality of heaven. Because history is still unfolding, Heaven remains open and is waiting to reach its fullness, which will occur at the end of the world. Only then will all of the members of the Body of Christ gather together and the "resurrection of the dead" will take place. At tht time, Christ's presence in all its fullness will penetrate the soul of every person who is saved and-with them-the entire universe. The cross has made union between God and man possible and created what would later be known as and called "heaven."

As Joseph Ratzinger writes, through the complete redemption of the individual man will be freed from his internal limitations and will open up to the Fullness that completes that which is unique to every individual. This union will overflow with joy, and every question will be fully answered. ${ }^{7}$

In one of his homilies, Benedict XVI said that man uses the term "Heaven" to express his intimacy with God."

\footnotetext{
Ibid, pg. 257.

Ibid, 258.
}

Benedict XVI, Homily for the Mass for the Solemnity of the Assumption of the Virgin Mary, August 15, 2010, http://www.vatican.va/content/benedict-xvi/en/ 
scends time. The doors to eternal life, which finds its source in God, are opened up before man. After the death of someone close, people sense the loved one's presence in a way that is difficult to explain. This Dogmatic Theology occurs within their memory, but also within the heart. The Holy Father says that those who are left behind and are on the path of the journey known as earthly life carry within themselves a part of the one who has passed. Unfortunately, as Benedict XVI points out, the ones who are left behind will one day pass away and their memory will pass with them. It is different, however, with God. Only God is beyond time, and $\mathrm{He}$ is the source of the eternal existence of created beings. Man is "the result of a thought of [the eternal] God;" therefore, he will never be forgotten. Joy, hope, harmony, and interior peace are based in Divine thought and love. Because of this, man is safe and his entire temporal existence is connected to the life of the eternal God. Through God, death is overcome through love and followed by eternal life. When understood in this way, God love is called "Heaven." God is great, and every being can find its place in Him. As the God-Man, Jesus is the surety that such a union is absolutely and eternally possible. Benedict $\mathrm{XVI}$ is not convinced that only a small part of man endures while the rest eventually disappears into the nothingness of forgetfulness after man dies. Rather, God knows and loves the entire person and includes everything that constitutes man now-suffering, love, hope, sadness, and joy-in eternity.

Pope Benedict XVI notes that the prospect of Heaven should fill every believer with deep joy. The Christian world's proposition is very concrete. Everything that is important, precious, and valuable to particular individuals will not be destroyed after death; instead, it will find its fullfillment in God. As St. Matthew writes in his gospel: "Even all the hairs of your head are counted." 10 This means that within the future world, temporality will be transformed (and not annhilated): "creation itself will be set free from slavery to corruption and share in the glorious freedom of the children of God." 11 The Christian undersanding of the world to come-"Heaven"-_gives Christians a strong

homilies/2010/documents/hf_ben-xvi_hom_20100815_assunzione.html (Accessed 01.01.2019).

Benedict XVI, Homily for the Imposition of the Pallium and Conferral of the Fisherman's Ring for the Beginning of the Petrine Ministry of the Bishop of Rome, April 24, 2005, http://www.vatican.va/content/benedict-xvi/en/homilies/2005/documents/hf_ben-xvi_hom_20050424_inizio-pontificato.html (Accessed 01.01.2019). 
Dogmatic Theology hope for a beautiful future that is also based on their present earthly existence. The Christian is called to build up the world in such a way that it will one day become a divine world that surpasses everything that man can achieve on his own.

On November 1, 1950, Pope Pius XII proclaimed the dogma of the Assumption, which upholds that Mary was assumed body and soul into Heaven after her earthly life. This truth of the faith was part of the Tradition of the Church and confirmed by the Fathers of the Church. It was also an important element of devotion to the Mother of Jesus Christ. ${ }^{12}$ As Benedict XVI points out, from the moment that Pope Pius XII proclaimed this dogma, many things changed, particularly the atmosphere in which future generations of Catholics lived. It is difficult for contemporary man to live with the joy and enthusiasm that the faithful experienced when the dogma of the Assumption of the Blessed Virgin Mary was proclaimed. For, at this time, the Church presented the truth about the human body-about its beauty and greatness-with a new passion. Delight spread throughout the entire land, which did not judge according to the past, but looked to the future and perceived its depth. By pointing to Mary, the Church loudly proclaimed to the world that she revealed the greatness of what humanity could be.

As Ratzinger writes, however, this dogma, which was at once a source of joy and hope, has caused many issues, and that is why it is overlooked. The questions that arise when individuals discuss the dogma of the Assumption of Mary and the difficulties that responses elicit cannot, however, obscure the deepest truth about man and the entire world's destiny. ${ }^{13}$

When comparing Jesus' Resurrection to Mary's Assumption, Pope Benedict XVI points out the fact that the Resurrection transcends time and, even though it is not a common historical fact, it does touch history and manifests itself in it. ${ }^{14}$ This, however, cannot be said about the Mary's Assumption, which-as the eminent Benedict notes-is a little documented event. ${ }^{15}$ For this reason, people should speak about the Assumption of the Blessed Virgin Mary as a theological (and

12 Benedict XVI, Homily for the Solemnity of the Assumption of the Blessed Virgin Mary, August 15, 2012, http://www.vatican.va/content/benedict-xvi/en/ homilies/2012/documents/hf_ben-xvi_hom_20120815_assunzione.html (Accessed 01.01.2019).

J. Ratzinger, Opera..., pg. 605.

14 J. Ratzinger, Wzniosta Córa Syjonu. Rozważania mariologiczne, Poznan 2002, pg. 48.

15 Por. Ł. Żak, "Josepha Ratzingera kultyczna interpretacja dogmatu o wniebowzięciu Maryi," Salvatoris Mater 9 (2007), nos. 3-4, pg. 143. 
not historical) reality. Elevating Mary to the glory of Heaven did not happened by the power of her own strength, bur rather by God the Father's initiative. ${ }^{16}$

Christianity is not a religion of the past that desires to tie man to something that once was. Rather, it is a religion that looks with hope to the future and opens up the path to that which will come-namely, to the ultimate, highest, and perfected state of creation. Pope Benedict XVI recalls that, despite the hardships and struggles of his daily life, man must perceive the beauty of the world to come. For the one who believes, this certainty should be a source of unwavering hope and deep joy, thanks to which he is able to cope better with what is still imperfect in the world. ${ }^{17}$

\section{Purgatory}

In addition to the two eternal realities of Heaven and Hell, there exists a third, temporary state that Catholic teaching calls "Purgatory." The Church defined Purgatory and its different aspects during the Middle Ages. The question of Purgatory was raised primarily during the Council of Lyon (1274), the Council of Florence (1439), and the Council of Trent (1563). According to the dictionary of theology, this concept is the process of purification and perfection of man in all of his dimensions after death. ${ }^{18}$

The "intermediate state" between man's death and his resurrection on the last day remains an open question in the New Testament. However, the concept of Purgatory was considered more closely because of the gradual development of Christian anthropology and its connection with Christology. The ultimate fate of man is decided at the moment of his death. This fate, however, does not have to be fulfilled at the moment of death. Pope Benedict XVI recalls that the Eastern Church, which upholds John Chrystosom's concept of the "intermediate state," does not share the Catholic Church's theology on the Purgatory. Unlike the Catholic Church, the Orthodox Church rejected the teaching on purification after death. Like the Catholic Church, however, the Eatern Church accepted the idea of interceding for the dead. One hundred years later, during the Council of Trent, however, the situation changed because this Council had to contend

16 J. Ratzinger., Wzniosła Córa Syjonu. Rozważania mariologiczne, Poznan 2002, pg. 49.

17 J. Ratzinger, Opera..., pg. 609

18 K. Rahner, H. Vorgrimler, Maty stownik teologiczny, Warsaw 1987, pg. 74. 
Dogmatic Theology

with the thought that arose during the Protestant Reformation. ${ }^{19} \mathrm{Un}$ like Greek Catholics, Protestants rejected any idea that had to do with expiation for sin after death. They argued (and continue to uphold) that universal reparation took place through Jesus' death on the cross. The doctrine of justification asserts that all forms of intercession for the dead such as prayer, almsgiving, good works, and the Eucharist are unnecessary and that man should value and rejoice in the knowledge that God arranges everything that man cannot. ${ }^{20}$

When seeking explanations for Purgatory and a new way to speak about it, Joseph Ratzinger examined what the three aforementioned Councils presented on the topic. He pointed out that the official texts of the Church avoid the vivid term "fire of Purgatory" and speak, instead, about purifying punishments or directly about "Purgatory." Each successive Council presented this matter in a simpler and more precise way until the Fathers of the Council of Trent developed this concise formula: "The Catholic Church, instructed by the Holy Spirit and in accordance with sacred Scripture and the ancient Tradition of the Fathers, has taught in the holy Councils and most recently in this ecumenical Council that there is a purgatory and that the souls detained there are helped by the acts of intercession (suffragia) of the faithful, and especially by the acceptable sacrifice of the altar."

Benedict XVI indicates that the source of the Church's teaching on "Purgatory" and the issues concerning the "intermediate state" can be traced back to the early Jewish age ${ }^{21}$ The Second Book of Maccabees, which dates back to the $1^{\text {st }}$ century $\mathrm{BC}$, says that pagan amulets were found on the bodies of Israelites who had fallen in battle:

On the following day, since the task had now become urgent, Judas and his companions went to gather up the bodies of the fallen and bury them with their kindred in their ancestral tombs. But under the tunic of each of the dead they found amulets sacred to the idols of Jamnia, which the law forbids the Jews to wear. So it was clear to all that this was why these men had fallen. They all therefore praised the ways of the Lord, the just judge who brings to light the things that are hidden. Turning to supplication, they prayed that the sinful deed might be fully blotted out. The noble Judas exhorted the people to keep themselves free from sin, for they had seen with their own eyes what had happened because of the sin of those who had fallen. He then took up a collection among all his soldiers, amounting to two thousand silver drachmas, which he sent to Jerusalem to provide for an expiatory sacrifice. In doing this he

\footnotetext{
$19 \quad$ J. Ratzinger, Śmierć ..., pg. 239.

20 P. Seewald, J. Ratzinger, Bóg $i$ świat, pg. 219.

$21 \quad$ J. Ratzinger, Śmierć..., pg. 240.
} 
acted in a very excellent and noble way, inasmuch as he had the resurrection in mind; for if he were not expecting the fallen to rise again, it would have been superfluous and foolish to pray for the dead. But if he did this with a view to the splendid reward that awaits those who had gone to rest in godliness, it was a holy and pious thought. ${ }^{22}$

According to this account, the Israelites died because they had deviated from the Law. In response, the people, offered up prayers of supplication for those who had sinned so that "the sinful deed might be fully blotted out." Benedict XVI highlights the fact that sacrificial offerings were made for the dead in Jerusalem. The author of $2 \mathrm{Mac}-$ cabees himself lauds such a response as an expression of faith in the resurrection.

In order to present the purifying action of prayer for the dead and the "intermediate state," Pope Benedict XVI refers to the Jewish apocryphal text entitled "The Life of Adam and Eve." This text was written during the $1^{\text {st }}$ century AD and describes the grief that Seth experiences after the death of Adam. The text emphasizes God's mercy, which God's messenger the Archangel Michael proclaims, saying "Rise up from the body of thy father and come to me and see what is the doom of the Lord God concerning him. His creature is he, and God hath pitied him."' Divine Mercy, however, still entails just punishment: "Then Seth saw the hand of God stretched out holding Adam and he handed him over to Michael, saying: 'Let him be in thy charge until the day of Judgment in punishment, till the last years when I will convert his sorrow into joy. Then he shall sit on the throne of him who hath been his supplanter." 23 Jewish traditions encounter Christian religious trends such that the boundaries of these thoughts are fluid in relation to each other, and the continuity of tradition is manifested in this. Clement of Alexandria (150-215 AD) and Tertullian (155-220 AD) represent different schools of thought on Purgatory in both the East and the West. Tertullian most likely wrote "The Martyrdom of Saints Perpetua and Felicity," which describes a vision in which Perpetua saw her younger brother, Dinocrates, who had died of cancer. In this vision, Dinocrates is pallid and has an open wound [on his face], which is the cause of the boy's death. In order to quench his own thirst, Dinocrates tries unsuccessfully to drink from a container of water that was too high for him to reach. St. Perpetua understood the meaning

2Macc 12:39-45.

${ }^{23}$ “Vitae Adae et Evae," Wesley Center Online, http://wesley.nnu.edu/sermonsessays-books/noncanonical-literature/noncanonical-literature-ot-pseudepigrapha/the-books-of-adam-and-eve/ (Accessed 01.01.2019). 
Dogmatic Theology

of this vision and began to pray unceasingly for her brother. In her next vision, she saw that her brother's face was healed and that he was healthy and joyful. When writing about Purgatory, Tertullian refers to Jesus' words: "Settle with your opponent quickly while on the way to court with him. Otherwise your opponent will hand you over to the judge, and the judge will hand you over to the guard, and you will be thrown into prison. Amen, I say to you, you will not be released until you have paid the last penny." 24 According to Benedict XVI, this was proof of the fact that the time between death and the resurrection is a period of imprisonment, in which the soul has the opportunity to "pay off [his debt]" in order to experience the resurrection. ${ }^{25}$ In response to the pastoral needs of his people during the persecution of Christians, St. Cyprian (200-258 AD) described Purgatory in a completely new way. According to the Bishop of Carthage, those who die professing the faith are martyrs and become saints and receive salvation immediately after their death. He also assured his faithful that Hell exists and that those who are condemned to Hell cannot leave. During this time, those who, on account of their weakness, denied the faith in order to avoid martyrdom posed a particular challenge. Frequently these individuals asked to be able to participate in the community of the Church once again. Recalling the passage from the beginning of St. Matthew's Gospel that was quoted above, St. Cyprian upheld that it was possible for individuals to continue penance after their death. For this reason, St. Cyprian opposed a rigorist approach that those who had separated themselves from the Church by denying their faith, and he welcomed them back into the Church community. Reintigrating apostates into the Body of Christ—-the Church-did not automatically restore their full communion with Christ; rather, it made it possible for them to continue penance for their sins both during their life on the earth and after their death. According to Joseph Ratzinger, this understanding clearly expresses the Western Church's doctrine on Purgatory. ${ }^{26}$

Like St. Cyprian in the West, St. Clement of Alexandria (150-212 AD) took up the issue of Purgatory in the East. In his assessment, St. Clement pointed to the ecclesial dimension of Purgatory and argued that the individual process of becoming perfect and being purified is connected with the intercession for others that arises from Christians' mutual concern for each other. According to St. Clement, the Church's penitential practices, which necessarily and occassionally

\begin{tabular}{ll}
\hline${ }_{24}$ & Mt 5:25-26. \\
25 & J. Ratzinger, Śmierć..., pg. 243. \\
26 & J. Ratzinger, Śmierć..., pg. 244.
\end{tabular}


extend beyond the limits of earthly life, are important to recall. In this instance, Pawłowo-Janowa's idea that the dividing line is not determined by earthly life and death, but by either being or not being with Christ comes to the fore. Baptism is the beginning of being a person's life in Christ, and, while death is decisive moment, this does not mean that a person's maturation in his with Christ cannot take place after he dies. Unfortunately, Origen, whose views were ultimately rejected by the Church, took up and made some changes to Pope Clement's concepts. St. John Chrystosom (350-407 AD) opposed Origen's theory of apocatastasis - or the idea that no one goes to Hell (Hell is empty), which was related to the idea of purgative fire. ${ }^{27}$ The Holy Father recalls that Greek Catholics still base their views on Purgatory on the thought of Byzantine bishops. While awaiting the resurrection after death souls all enter into an "intermediate state" that, depending on an individual's behavior during his earthly life and the depth of his union with Christ, entails varying degrees of happiness and suffering. Through participation in the Eucharist, prayer, and almsgiving, those living on the earth can "assist" the soul in "Hades" by bringing them "breath and refreshment." Benedict XVI notes that this intervention can neither alleviate the suffering that purifies nor is it a penance for sins committed. Similiarly, the saints in Heaven, on the other hand, can intercede for those who ask for their help.

When discussing the Church Fathers' teaching on Purgatory, Pope Benedict XVI refers to a passage from the First Letter of St. Paul to the Corinthians: "According to the grace of God given to me, like a wise master builder I laid a foundation, and another is building upon it. But each one must be careful how he builds upon it, for no one can lay a foundation other than the one that is there, namely, Jesus Christ. If anyone builds on this foundation with gold, silver, precious stones, wood, hay, or straw, the work of each will come to light, for the Day will disclose it. It will be revealed with fire, and the fire [itself] will test the quality of each one's work. If the work stands that someone built upon the foundation, that person will receive a wage. But if someone's work is burned up, that one will suffer loss; the person will be saved, but only as through fire." 28 The German Catholic theologian Joachim Gnilka points out that Christ is this fire and disagrees with his fellow countryman, the German theologian J. Jeremis, who thought that this passage refers to the purgative fire. In his interpretation of both positions, Benedict XVI reconciles the fire of purgatory with the personal

$27 \quad$ Ibid, pg. 247.

$28 \quad 2$ Cor $3: 10-15$. 
Dogmatic Theology fire that is Christ. The Pope believes that, when understood in a Christological way, Purgatory takes on a strictly Christian essence. In fact, this is how the Christianization of the Jewish concept of purgatory took place. ${ }^{29}$ Christ is the fire that judges man, transforms him, and moulds him according to the image of His glorified Body: "But our citizenship is in heaven, and from it we also await a savior, the Lord Jesus Christ. He will change our lowly body to conform with his glorified body by the power that enables him also to bring all things into subjection to himself." 30

After death, man enters into the reality of Christ, Who ultimately determines his fate. At this moment, the human being is immersed in the eschatological fire. One should not judge and limit the "moment" at which man is transformed, becomes perfected, and is exalted according to the confines of the human measure of time. While this moment certainly is not eternity - as Benedict XVI declares-it is certainly common naivete to determine whether this moment lasts for a short or long time. In this case, the measure is the depth of the uniqueness of the human spirit, which must be uncovered and consumed by the fire of an encounter with the Most High God. ${ }^{31}$

According to Benedict XVI, the current Christian interpretation of Purgatory is not based-as Tertulian's understanding of Purgatory was-on the concept of an appointed place in the afterlife where imperfect man must go in order to suffer his punishment. Today's concept of Purgatory is connected to the process of conversion that is indispensibles for man's purification of his weaknesses and imperfections so that he may stand before the face of a perfect God and the entire company of saints. The action of the aforementioned fire does not supercede the gift of grace in man. Thanks to this purifying fire, however, grace reaches its fulfillment. Man is unable to free himself from egoism, even if he cooperates with the gift of grace. Therefore, something more is necessary - namely, complete transformation. The purifying fire of Purgatory makes this transformation possible because it burns away that which is built of "hay, wood, and straw" in man's life. Ratzinger emphasizes that man should perceive penance as a form of grace and not a denial of it. ${ }^{32}$ Very few people lead completely pure and perfect

29 Benedict XVI, Encyclical Spe salvi, Vatican City, 2007, http://www.vatican.va/ content/benedict-xvi/en/encyclicals/documents/hf_ben-xvi_enc_20071130_spesalvi.html.

$30 \quad$ Phil 3:21.

$31 \quad$ J. Ratzinger, Śmierć..., pg. 249.

$32 \quad$ Ibid, pg. 251. 
lives. Despite such widespread fallibility, man's longing for the good typically remains the determining factor. Because $\mathrm{He}$ is all-powerful, God can take what is imperfect in man and make something good out of it. This cannot take place, however, without Purgatory, where the gaze of Christ purifies man once again. Thanks to this purification, man is able to enter into God and dwell with Him. ${ }^{33}$

Joseph Ratzinger presents arguments that state that prayer for the dead is one of the oldest Christian and Jewish Traditions. Despite this, however, he also points out that it is also possible to understand Purgatory as a kind of external punishment that can be shortened and lessened by grace as well as a kind of spiritual "exchange" wherein those living on earth can take on the punishment due to others. The Holy Father demonstrates how this understanding is erroneous by emphasizing the personal character of Purgatory along with its inherently Christological dimension. This also leads to the second issue-namely, some perceive the suffering of the soul in terms of "having," rather than as it should be understood: in terms of individual, irreplaceable "being." Devotions for the souls of the dead very often are to blame for this state of affairs. It is important to note, however, that no man is an island separated from everyone else; for man always turns toward others and reaches out to touch them through his activity, and this touch is one of grace or guilt, love or hatred. Whether people bless, curse, or forgive each other, thereby transforming their guilt into love, all of this is part of their fate. The Book of Revelation says: "They came to life and they reigned with Christ." 34 The saints' reign means that they have taken hold of their inheritance and carry out judgment with the Lord: "Do you not know that the holy ones will judge the world? If the world is to be judged by you, are you unqualified for the lowest law courts?" 35 The truth about Purgatory and the Christian practices that have followed from it recognize that the saints as participants in God's judgment and as intercessors for those who are judged.$^{36}$ Intercession that is imbued with charity signified that a person is offering himself for another, which is the essence of Christianity. Church teaching on Purgatory upholds that death by no means places any limits on this charity. Men can mutually help each other both during their earthly life and after death. As Benedict XVI demonstrates, this has been the belief since the time of the Old Testament: "Give your gift to all the living,

P. Seewald, J. Ratzinger, Bóg i świat, pg. 218.

34

Rev 20:4.

35

1Cor 6:2.

36

J. Ratzinger, Śmierć..., pg. 252. 
Dogmatic Theology

and do not withhold your kindness from the dead"37 and throughout the Tradition of the Church in both the East and the West. Opposition to this understanding didn't occur until Protestant denominations that grossly misunderstood the pious practices of the time arose..$^{38}$

Benedict XVI notes that the Catholic vision Purgatory contains something extraordinarily human. For, he believes that, even if Purgatory did not exist, man whould have to invent it because no one would feel worthy or strong enough to stand before the face of the Most High God. No man would want to be considered a defective and discarded work of his Creator. Every person has within his heart a desire to be mended and healed. Purgatory is precisely this transformation that will purify man of that which is corrupted and imperfect in such a way he can stand before God, dwell in Him forever, and enjoy complete fulfillment. ${ }^{39}$

\section{Hell}

According to the dictionary of theology, "hell" is the absence of blessed union with God and the positive punishments (that take place within the realm of Purgatory). Hell is the state of a person who has ultimately and personally turned away from God and the order of created things. The teaching of Magisterium of the Church affirms the existence of hell. Man experiences a space devoid of God immediately after his death, and not after his judgment. This state is neither temporary nor revocable, but eternal. The dogma of Hell emphasizes that there is the risk and very real threat that man's life could turn out to be completely and eternally unfilfilled through the choices that he freely makes, which can also ultimately lead him to reject God. Neither Revelation nor the Catholic Church says anything regarding the extent to which this reality can be realized in man. Biblical passages that refer to Hell do not so much convey information about it that would satisfy man's curiosity, but call man to repentance and conversion. God wants to save every person, but it is possible for man to reject this gift. ${ }^{40}$

Jesus says, "Enter throught the narrow gate; for the gate is wide and the road broad that leads to destruction, and those that enter through it are many. How narrow the gate and constricted the road that leads

\footnotetext{
$37 \quad$ Sir 7:33.

38 J. Ratzinger, Śmierć..., pg. 253.

$39 \quad$ P. Seewald, J. Ratzinger, Bóg i świat, pg. 218.

$40 \quad$ K. Rahner, H. Vorgrimler, Maty stownik teologiczny, Warsaw 1987, pg. 325.
} 
to life. And those who find it are few." ${ }^{41}$ Another passage of Scripture speaks about a large crowd that is gathered around the throne of the Lamb: "After this I had a vision of a great multitude, which no one Dogmatic Theology could count, from every nation, race, people, and tongue. They stood before the throne and before the Lamb, wearing white robes and holding palm branches in their hands." ${ }^{42}$ The Successor of Peter [Benedict XVI] interprets the first passage to be a pragmatic warning rather than a description of reality. The person who leads a comfortable and easy life and behaves like others-while he certainly enjoys this in the moment-moves further away from the Source of true life. The only appropriate choice is to follow the difficult and demanding way that, according to Christ, is the narrow path and gate through which one must pass with great effort. This strong image is meant to show people the truth that "when man drifts and only goes along with the current, when he loses himself in the masses, his habitat always becomes the mass and emptiness in the end. The courage to flee and effort will set him back on the right path." ${ }^{43}$ Benedict XVI also points out that, when interpreting this passage of Gospel, one can easily be convinced that Hell is already full and Heaven is empty. The Pope argues, however, that certain passages of Scripture should not be interpreted literally, but, instead, "seen" within the broader context of Jesus' teachings.

The concept of eternal damnation was formed very clearly in Judaism in the two hundred years before Jesus' birth. The Bible refers to this topic very often, Jesus Himself speaks about it in the Gospels, and His Apostles include it in their writings. ${ }^{44}$

The Catechism of the Catholic Church states that man cannot be united with God unless he freely chooses God's love. To commit sins against the Creator or one's neighbor is contrary to love: "We know that we have passed from death to life because we love our brothers. Whoever does not love remains in death. Everyone who hates his brother is a murderer, and you know that no murderer has eternal life remaining in him." ${ }^{45}$ To die in a state of mortal sin, without contrition and rejecting God's merciful love, indicates a choice to definitively and ultimately separate onself from God and to exclude oneself from

\footnotetext{
$41 \quad$ Mt 7:13-14.

$42 \quad \operatorname{Rev} 7: 9$.

$43 \quad$ P. Seewald, J. Ratzinger, Bóg i świat, pg. 265.

$44 \quad$ J. Ratzinger, Opera..., pg. 203.

45 1Jn 3:14-15.
} 
Dogmatic Theology union with Him and His saints. The Catechism of the Catholic Church specifies this state as "hell." 46

According to Pope Benedict XVI, the strong feelings that the concept of "Hell" evokes have been evident throughout the centuries throughout which this concept was formed. As the Benedict XVI notes, the definition of Hell has differed greatly from human notions about God and man. Origen, who tried to systematize Christian teaching, thought that, according to the Divine logic of history, universal reconciliation will take place at the end of time. According to Ratzinger, this was Origen's attempt to convey a particular idea within the framework of a significantly broader theory that he could substantiate because Origen was unable to show the specific reality of this theory. As a result of Neoplatonic thinking, evil was perceived as the absence of the good, as nothing, and God as the only existing value. Origen's thought has persisted throughout the centuries and his so-called "teaching on mercy" has taken on different forms. This thought either rejected the possibility that Christians could be damned or asserted that, because mercy is one of God's attributes, God grants a certain amnesty to everyone-a mitigation in the face of a just judgment. ${ }^{47}$

In light of Origen's thoughts on Hell, Ratzinger emphasizes the fact that creation was endowed with unconditional freedom by the will of the Most High God. By descending into hell, Christ rids it of suffering, but not automatically by ignoring man's freedom. Man is not so incapacitated that he is unable to receive such a magnificent gift as God's love for His creation. Man is responsible for his fate. Freedom, therefore, is integral to Heaven and serves as the basis for it because such freedom makes it possible for man to reject God and choose the path of eternal damnation. The Church's unique teaching on man and his freedom arises directly from Her appreciation for the greatness of man and of that with which God has endowed man. The life of every individual is important and unique, and in the end God will not change everything that occurs in man's life and the consequences that follow. If this were to occur, then the Creator would then seem to be the great manipulator, against Whose plan man can in no way defend himself. The gravity of human life lies in the fact that certain aspects of and events in man's life are irrevocable, including the possibility that he is free to choose irrevocable destruction. Every person who professes Christ, Whose gravity of life and its consequences took on the form of the Cross, must live with this awareness. Perceiving the suffering

$46 \quad$ Catechism of the Catholic Church, 1033.

$47 \quad$ J. Ratzinger, Opera ..., pg. 204. 
and death of Jesus, Ratzinger points out that the evil that the Son of Man experiences is not a farce or unreal. He Who is Love experienced what it is to be really and truly hated. Christ did not overcome evil Dogmatic Theology through theological debate or theories but by concretely confronting it in the reality of Good Friday. The Love of the Christ is so strong that it is able to descend into Sheol, and it has the power to effect change by respecting the freedom of the beloved and allowing this change to take place. Man cannot fully comprehend the deep significance of God's descent into Hell. He can, however, ascertain this depth by experiencing in complete faith the suffering of the presence of the Most High to the very limit of his strength. Thus, the saints in recent centuries, especially Sts. John of the Cross and Therese of Lisieux, understood Hell in a different way. They no longer perceived Hell as a threat that one person can make against another, but as rather, they understood it more in terms of their vocation to encounter Christ. ${ }^{48}$

Man's greatest enemy is his attachment to sin, which is able to destroy his life. And, this destruction is permanent and eternal if man freely chooses to reject God's love from which forgiveness flows. ${ }^{49}$

When describing what Hell is, Jesus often uses the words "wailing and grinding of teeth." ${ }^{50}$ According to Joseph Ratzinger, these words appear in liminal statements. They are indicative of someone who is facing a particular danger and threat, and they also suggest the state of man who has lost his life. Benedict XVI believes this expression describes people who lead a life similar to an addict who has become addicted to drugs or other things and who, awakening from his artificial sleep, perceives the complete failure of his lives. Although the concept of Hell calls to mind images of a burning fire, "gashing of teeth" occurs when one is cold. The man who has hit rock bottom often cries, laments, rebels, and has the impression that he has been overcome by a coldness of heart that is the consequence of rejecting God's love. A world that is separated completely from its Creator and thus His Love begins to grow cold and ultimately freezes to the point that it grinds its teeth. ${ }^{51}$

$48 \quad$ J. Ratzinger, Śmierć..., pg. 238.

49 Benedict XVI, Homily During the Mass at St. Felicity and Her Children, Martyrs parish, March 25, 2007, http://w2.vatican.va/content/benedict-xvi/en/ homilies/2007/documents/hf_ben-xvi_hom_20070325_visita-parrocchia.html (Accessed 01.01.2019). 
Dogmatic Theology

\section{Bibliography:}

1. Benedict XVI, Encyclical Spe salvi, Vatican City, 2007, http://www. vatican.va/content/benedict-xvi/en/encyclicals/documents/hf_ben-xvi_ enc_20071130_spe-salvi.html.

2. Benedict XVI, Homily During the Mass at St. Felicity and Her Children, Martyrs parish, March 25, 2007, http://w2.vatican.va/content/benedict-xvi/ en/homilies/2007/documents/hf_ben-xvi_hom_20070325_visita-parrocchia. html (Accessed 01.01.2019).

3. Benedict XVI, Homily for the Imposition of the Pallium and Conferral of the Fisherman's Ring for the Beginning of the Petrine Ministry of the Bishop of Rome, April 24, 2005, http://www.vatican.va/content/benedictxvi/en/homilies/2005/documents/hf_ben-xvi_hom_20050424_inizio-pontificato.html (Accessed 01.01.2019).

4. Benedict XVI, Homily for the Mass for the Solemnity of the Assumption of the Virgin Mary, August 15, 2010, http://www.vatican.va/content/benedictxvi/en/homilies/2010/documents/hf_ben-xvi_hom_20100815_assunzione. html (Accessed 01.01.2019).

5. Benedict XVI, Homily for the Solemnity of the Assumption of the Blessed Virgin Mary, August 15, 2012, http://www.vatican.va/content/benedict-xvi/ en/homilies/2012/documents/hf_ben-xvi_hom_20120815_assunzione.html (Accessed 01.01.2019).

6. Rahner K., Vorgrimler H., Maty słownik teologiczny, Warsaw 1987.

7. Ratzinger J., Opera Omnia, Vol. X, Lublin 2014.

8. Ratzinger J., Śmierć $i$ życie wieczne [Eschatology: Death and Eternal Life], Warsaw 1986.

9. Ratzinger J., Wzniosta Córa Syjonu. Rozważania mariologiczne, Poznan 2002.

10. Seewald P., Ratzinger J., Bóg i świat [God and the World], Cracow 2005.

11. "Vitae Adae et Evae," Wesley Center Online, http://wesley.nnu.edu/ sermons-essays-books/noncanonical-literature/noncanonical-literatureot-pseudepigrapha/the-books-of-adam-and-eve/ (Accessed 01.01.2019).

12. Żak Ł., "Josepha Ratzingera kultyczna interpretacja dogmatu o wniebowzięciu Maryi," Salvatoris Mater 9 (2007), nos. 3-4. 